\title{
AVAILABLE EVIDENCE AND OUTCOME OF OFF-LABEL USE OF RITUXIMAB IN CLINICAL PRACTICE
}

Danés $\mathrm{I}^{1}$, Agustí $\mathrm{A}^{1}$, Vallano $\mathrm{A}^{2}$, Martínez $\mathrm{J}^{3}$, Alerany $\mathrm{C}^{3}$, Ferrer $\mathrm{A}^{4}$, López $\mathrm{A}^{5}$, Cortés-Hernández $\mathrm{J}^{6}$, Bosch $\mathrm{JA}^{6,7}$.

Running title: OFF-LABEL USE OF RITUXIMAB.

${ }^{1}$ Clinical Pharmacology Service, Fundació Institut Català de Farmacologia, Hospital Universitari Vall d'Hebron, Department of Pharmacology, Therapeutics and Toxicology, Universitat Autònoma de Barcelona.

${ }^{2}$ Clinical Pharmacology Service, Hospital Universitari de Bellvitge, IDIBELL, Department of Pathology and experimental Therapeutics, Universitat de Barcelona, Hospitalet de Llobregat.

${ }^{3}$ Pharmacy Service, Hospital Universitari Vall d'Hebron, Barcelona.

${ }^{4}$ Pharmacy Service, Hospital Universitari de Bellvitge, Hospitalet de Llobregat.

${ }^{5}$ Haematology Service, Hospital Universitari Vall d'Hebron, Barcelona.

${ }^{6}$ Internal Medicine Service, Hospital Universitari Vall d'Hebron, Barcelona.

${ }^{7}$ Medical Direction, Hospital Universitari Vall d'Hebron, Department of Internal Medicine, Universitat Autònoma de Barcelona. Spain.

Corresponding author: Imma Danés, Clinical Pharmacology Service, Fundació Institut Català de Farmacologia, Hospital Universitari Vall d'Hebron, Universitat Autònoma de Barcelona. Spain.

e-mail address: id@icf.uab.cat

Telephone (34-93) 4283029

FAX (34-93) 4894108. 


\section{Abstract}

Purpose: To analyze the therapeutic indications for off-label use of rituximab, the available evidence for its use, the outcomes, and the cost.

Methods: Retrospective analysis of patients treated with rituximab for off-label indications from January 2007 to December 2009 in two tertiary hospitals. Information on characteristics of patients, medical conditions and therapeutic responses was collected from medical records. Available evidence for the efficacy of rituximab in each condition was reviewed and the cost of treatment was calculated.

Results: A total of 101 cases of off-label rituximab use were analyzed (median [IQR] age 53 years [37.5-68.0]; 55.4\% women). The requested indications were mainly haematological diseases (46\%), systemic connective tissue disorders $(27 \%)$ and kidney diseases (20\%). Available evidence in these indications were mainly individual cohort studies (53.5\% of cases), and case series $(25.7 \%)$. Short-term outcome (median 3 months [IQR 2-4]) was a complete response in $38 \%$ of cases and partial response in $32.6 \%$. The highest short-term responses were observed for systemic lupus erythematosus and membranous glomerulonephritis, and the lowest for neuromyelitis optica, idiopathic thrombocytopenic purpura, and miscellaneous indications. Some response was maintained in long-term follow-up (median 23 months [IQR 12-30]) in $69.2 \%$ of patients with short-term response. Median cost per patient was $€ 5,187.5$ (IQR 5,187.5-7,781.3).

Conclusions: Off-label rituximab is mainly used for the treatment of haematological, kidney and systemic connective tissue disorders, and the response was variable depending on the diseases. The level of evidence in these indications was low and the cost very high. More clinical trials are needed, although they can be difficult in some rare diseases. Data from observational studies may provide useful information to assist prescribing in clinical practice.

Keywords: "Drug therapy"; "Off-label use"; "Efficiency"; "Pharmacy and Therapeutics Committees"; "Rituximab". 


\section{INTRODUCTION}

In Spain the regulation for off-label drug prescriptions changed in 2009. The change has allowed the use of drugs for unapproved indications to be taken by the prescribing physician and the patient, who must consent to treatment after being properly informed [1]. Off-label use should be an exception and limited to situations in which there is a lack of approved alternatives for a particular patient. Authorization from the Regulatory Agency is not required now. Although the procedure is easier, this may facilitate the use of drugs with less conclusive evidence of efficacy, with greater uncertainty regarding their toxicity and often at a high cost. This worries hospital medical directors and health managers, because they can have doubts about the adequacy of financing drugs with insufficient or very limited data on efficacy. That's why, in accordance with the Catalan Health Service procedures [2], the Pharmacotherapeutics Committees in the public hospitals assess each case in order to verify if they fulfil the above conditions and to advise the Medical Directors.

Rituximab is one of the most frequently requested off-label drugs in our hospitals [3]. Rituximab is the first anti-CD20 monoclonal antibody to be marketed. CD20 antigen regulates the early steps of activation and differentiation of $B$ lymphocytes [4]. Rituximab was approved by the EMA in 1998 to be used in patients with stage III-IV follicular lymphoma who are chemoresistant or are in their second or subsequent relapse after chemotherapy. Since then, EMA indications for rituximab have broadened and can be used in first line treatment and maintenance of previously specified types of lymphoma. It has also been approved for CD20 positive diffuse large B cell non-Hodgkin's lymphoma in combination with CHOP chemotherapy, rheumatoid arthritis, and chronic lymphocytic leukemia [5].

Nevertheless, there is an increasing use of rituximab in off-label haematological and non-haematological conditions, where B-cells and autoantibodies are thought to play an important role in their pathophysiology. Although several authors have analyzed the off-label use of rituximab in patients with specific 
diseases, mainly systemic lupus erythematosus, lupus nephritis and other severe refractory systemic autoimmune diseases [6-12], data on its use in different off-label indications are scarce [13-15]. The aim of this study was to analyze the indications for off-label use of rituximab in our centres, the available evidence when it was used, the outcomes of treated patients, as well as the cost.

\section{METHODS}

A retrospective longitudinal study of patients treated with rituximab for off-label indications from January 2007 to December 2009 in two tertiary hospitals in the Spanish public health system $(\mathrm{H}$. Universitari Vall d'Hebron and Hospital Universitari de Bellvitge) was carried out. Patients treated with rituximab were identified from a Pharmacy register of requests for its off-label use. A retrospective review of medical records was conducted to get information about the patients (demographic data), their disease (indication for rituximab use, clinical, biological and image data to analyze its stage), dosage and treatment regimen of rituximab, previous and concurrent treatments, and outcome in short and long-term after treatment with rituximab. Patients' information and their clinical progress before and after rituximab treatment were verified conducting an audit of clinical records and consulting the clinicians responsible for patients care. Response was defined for each disease as complete (CR), partial (PR) or no response (NR) taking into account different parameters for each disease. In lupus nephritis and other glomerulonephritis, outcome measures included mainly proteinuria (CR: proteinuria $\leq 500 \mathrm{mg} / 24 \mathrm{~h}$; PR: improvement $\geq 50 \%$ ). In patients with systemic lupus erythematosus, symptoms and scores of disease activity were considered (CR: Systemic Lupus Erythematosus Disease Activity Index [SLEDAI] $\leq 4$ or clinical remission; PR: improvement $\geq 50 \%$ in SLEDAI). In patients with non-Hodgkin lymphoma response was assessed with hematological parameters and computerized tomography (CR: normalization of nodes, spleen, liver and biochemistry; PR: decrease of lymph node size $\geq 50 \%$ ) [16], and in patients with idiopathic thrombocytopenic purpura, the main 
outcome was the number of platelets (CR: platelet count $>150 \times 10^{9} / \mathrm{L}$; PR: platelet count $\left.>50 \times 10^{9} / \mathrm{L}\right)$.

A search in PubMed was performed to assess the available evidence of rituximab in each clinical indication when it was requested. Available evidence for each disease was classified according to Oxford Centre for Evidence-based Medicine criteria [17]. In addition, information on ongoing clinical trials for each indication of rituximab was obtained from the clinicaltrials.gov register [18]. ICD10 version was used to classify medical indications for rituximab use. To analyze the cost of treatment, the price of the drug marketed in Spain (Mabthera ${ }^{\circledR}$ ) at the time of the study was taken into account. The total cost of treatment administered during the study period for each patient and for each indication was calculated.

The study was conducted according to international ethical recommendations. In accordance with the national directives in relation to post-authorization studies, the study was approved by the Ethics Committee of Clinical Investigation in each participating hospitals.

Descriptive analysis of categorical and continuous variables was performed by means of the distribution of frequencies and proportions, median and interquartile range. Statistical differences were assessed using the chi-square test. Significance was set at a level of 0.05 , and was two-tailed. The statistical analysis was performed using IBM SPSS Statistics version 19 statistical package (SPSS, Chicago, IL,USA).

\section{RESULTS}

One hundred and one cases of off-label use of rituximab were identified and included in the study. All the patients were adult, with a median age of 53 years (interquartile range [IQR] 37.5-68.0), and 55.4\% were female. The main medical specialities of prescribers were Haematology (33.7\%), Internal Medicine 
(30.7\%), and Nephrology (21.8\%). The requested indications for rituximab use were haematological neoplasms (33\%) and other haematological diseases $(13 \%)$, systemic connective tissue disorders, including lupus nephritis $(27 \%)$, kidney $(20 \%)$ and neurologic diseases $(7 \%)$ (see table 1 ).

Most patients $(97 \%)$ had received other treatments before the request for rituximab off-label use. The median number of previous pharmacological treatments was 3 (IQR 2-4), and for haematological conditions treated with chemotherapy the median number of previous regimens was 2.5 (IQR 1-3).

Available evidence for rituximab use in these off-label indications was level $2 b$ (based on individual cohort study) in $53.5 \%$ of cases, level 4 (based on case series) in $25.7 \%$, level 2a (systematic review of cohort studies) in $10.9 \%$ of cases, level 1a (systematic review of randomized controlled trials) in $8.9 \%$, and level 5 (based on expert opinion) in only $1 \%$ of cases. Table 1 shows the levels of the available evidence for rituximab in the requested conditions. A level of evidence 1a or 2a was available in $42.5 \%$ of haematological cases and in none of the other cases. In the majority of indications some clinical trials were ongoing: phase 3 trials for $69.3 \%$ of requests and phase 2 for $15.8 \%$ (see table 1).

In 7 cases rituximab was not administered despite the request. In chronic lymphocytic leukemia and in the majority of lymphoma cases, the most commonly prescribed dose was $375 \mathrm{mg} / \mathrm{m}^{2}$ for $6-8$ cycles (the median number of administered cycles was 4). In the other diseases the dose was $1 \mathrm{~g} \mathrm{IV}$ two weeks apart in 37 cases or $375 \mathrm{mg} / \mathrm{m}^{2}$ weekly for 4 weeks in 12 cases.

The short-term outcome, after a median period of 3 months (IQR 2-4), was available for 92 cases (2 were lost in follow up), and the observed outcome was classified as complete response in 35 cases $(38 \%)$ and partial in $30(32.6 \%)$. Therefore, some response was observed in 65 (70.6\%) patients and no response in $27(29.4 \%)$. The observed outcome depending on the disease is shown in table 2. The highest short-term responses, complete or partial, were 
observed in patients with systemic lupus erythematosus, follicular non-Hodgkin lymphoma and membranous glomerulonephritis (100\% of cases), mantle-cell non-Hodgkin lymphoma (83.3\%) and lupus nephritis (77.8\%). Meanwhile, the lowest short-term response was observed for neuromyelitis optica and idiopathic thrombocytopenic purpura $(50 \%)$, large B-cell non-Hodgkin lymphoma (40\%), and the pooling of miscellaneous indications (36\%).

The median long-term follow-up period was 23 months (IQR 12-30). In longterm period, 45 out of 65 patients with short-term response $(69.2 \%$ of them and almost half of the total) maintained some effectiveness (29 complete response and 16 partial response), although 19 patients continued receiving other treatments or additional doses of rituximab. The long-term response was low in some haematological conditions such as chronic lymphocytic leukemia (27.3\%) and mantle-cell non-Hodgkin lymphoma ( $0 \%)$. In contrast, long-term outcome of patients with membranous glomerulonephritis (83.3\%), follicular non-Hodgkin lymphoma (75\%), and lupus nephritis (72.2\%) was high. A more detailed description of demographics and clinical course of patients with the most frequent diseases are shown in table 3. A relationship was found between the level of available evidence and the short-term outcome: some response (complete or partial) was described in $77.6 \%$ of cases of diseases with a high level of evidence ( 1 or 2 ) and in $52 \%$ of cases with a lower level of evidence $(p=0.016)$.

At least one adverse reaction was described in medical records in $27.7 \%$ of patients. A total of 47 adverse reactions were registered. The most commonly reported were nausea, vomiting, diarrhoea, pyrexia, sepsis, constipation, urinary tract infection and neutropenia. Eleven adverse effects (23.4\%) were considered serious: 7 infections, 2 cases of gastrointestinal bleeding, oedema (1) and mucositis (1); in 8 of these cases the patient was also treated with chemotherapy. In 4 patients treatment was discontinued due to the adverse drug reaction. 
The total budget for rituximab treatment during the study period was $€$ 677,901.18, and the median cost per patient was $€ 5,187.5$ (IQR 5,187.5$7,781.3)$. The most expensive indications were neuromyeltis optica, with a median cost of $€ 14,151.3$ (IQR 5,332.6-31,820.1), and mantle-cell non-Hodgkin Iymphoma (6,948.7; IQR 5,524.7-12,450); the cheapest were those in which the drug is administered locally, such as conjunctival MALT lymphoma ( $€ 52$ ) and marginal zone lymphoma of the skin ( $€ 521,7$ ). Median cost during the study was slightly higher for patients with diseases with a low level of evidence ( 3 or less) for rituximab $(5,477.6$; IQR $3,912.6-7,781.3)$ than for those with a high level of evidence $(5,187.5 ; 5,187.5-8,083.3)$. The total cost of non-responders was $€ 171,245.37$ ( $25.3 \%$ of the total budget).

\section{DISCUSSION}

The results of the study show that off-label use of rituximab was mainly for the treatment of haematological, kidney and systemic connective tissue disorders. Available evidence for rituximab in these diseases was low, because it was mainly based on cohort studies and case series, while in most cases phase 3 or 2 clinical trials were ongoing at that time. The short-term response was quite good, taking into account that patients were usually refractory to other treatments, and almost half of the total maintained this response long-term. Nevertheless, the response was variable according to the different indications. Off-label use of rituximab was very expensive. Off-label use of rituximab in different indications has also been assessed in other studies [13-15], although this study is the largest one in which evidences-based indications as well as patients' short and long-term outcomes and cost have been evaluated.

Haematological diseases were also frequent off-label indications of rituximab in other studies [14, 15]. Nevertheless, in our study non-haematological indications such as kidney and systemic connective tissue diseases have also been frequent. These results are in accordance with an increasing use of 
rituximab in other non-haematological off-label conditions where humoral immunity appear to play a role in their pathophysiology [13].

Few studies have assessed the level of evidence of off-label rituximab use. In the study of van Allen et al [14], in which different criteria for stratifying evidence were used, $47.1 \%$ of rituximab off-label administrations were classified with uncertain or inadequate levels of evidence and $52.9 \%$ with an adequate evidence-base for use. In our study, at the moment of the rituximab off-label request, the level of its published evidence was low and varied according to the diseases, and for most conditions phase 3 or 2 clinical trials were ongoing. These results suggest that although some kind of research is being carried out, decisions regarding off-label use of rituximab are difficult with the available evidence at the moment of off-label request.

The response rate in our study is comparable to that reported in other similar studies [13], also conducted in tertiary hospitals. It is noteworthy that in our study the overall rate of response includes the rituximab use in diseases that are currently approved, but that were not authorized when they were requested as off-label use. Nevertheless, the exclusion of these indications did not modify the overall response rate $(71.2 \%)$. Results observed in patients with follicular non-Hodgkin lymphoma were in accordance with those of clinical trials [19], although it was administered with a non-authorized combination with bendamustine. In patients with chronic lymphocytic leukemia the response rate decreased in the long-term follow-up. In a randomized clinical trial using rituximab and chemotherapy, after a median follow-up of two years, a significantly improved progression-free survival and response rate was observed in patients who had been previously treated for chronic lymphocytic leukemia [20]. The differences between these findings and our results may be due to the patients' characteristics; in our study patients were older, and the majority of them (82\%) had previously been treated with two or more chemotherapeutic regimens. Otherwise, the outcomes of most patients with diffuse large B-cell non-Hodgkin lymphoma were disappointing. Early clinical trials have shown that the addition of rituximab to the $\mathrm{CHOP}$ regimen increases 
the complete-response rate and prolongs event-free and overall survival in elderly patients with this condition [21-23]. Once again, the poor results observed in our study might be explained by the fact that the prognosis was worse in our cases, including people who had relapsed or had a refractory disease, and because rituximab was given in combination with other chemotherapies (gemcitabine and oxaliplatin).

For other diseases, rituximab is not approved but some clinical trials have recently been published. In patients with mantle-cell non-Hodgkin lymphoma, the short-term partial and complete response rate was high, but their long-term responses were null, as usual. This is in accordance with the published results [19]. Recently, the results of a clinical trial have shown that rituximab in combination with chemotherapy followed by maintenance therapy with rituximab may improve the overall long-term survival in older patients with mantle-cell lymphoma [24].

Two clinical trials with rituximab in patients with lupus have not confirmed the efficacy suggested by case-series and recent cohort studies [6-12]. In the EXPLORER trial that included patients with moderately-to-severely active systemic lupus erythematosus, no differences in the proportion of patients achieving and maintaining a partial or complete response were found between rituximab and placebo [25]. These results contrast with those of our study but criteria used in this trial differ from ours. Refractory patients and those recently treated with a cyclophosphamide or a calcineurin inhibitor were excluded in this trial. However, most of these patients were included in our study and other open-label studies and case reports [26]. Furthermore, the LUNAR trial that included patients diagnosed as having lupus nephritis class III or IV did not find any differences in the overall response rate between rituximab and placebo [27]. Criteria used to assess the efficacy in this trial also differ from our ones, as well as the severity of patients. Although in our study the patients were also diagnosed with lupus nephritis class III or IV and treated with mycophenolate mofetil and corticosteroids, they had a longer and more serious history of disease than patients included in the LUNAR trial. Furthermore, the high 
response rate reported in the placebo arm may partially be explained by the fact that their patients were not as seriously ill as ours [28]. Given these results, it would be reasonable to support the use of rituximab in patients with lupus in the setting of a clinical trial in refractory population.

In adults with previously untreated primary immune thrombocytopenia, one clinical trial has been published [29]. Sustained response (ie, platelet count $>$ or $=50 \times 10^{9} / \mathrm{L}$ after a 6 month follow-up period) was significantly greater in patients treated with dexamethasone and rituximab than in those treated with dexamethasone alone (63\% vs $36 \%$, respectively). In a systematic review of observational studies rituximab resulted in a pooled response rate of $62.5 \%$ with a median duration of response of 10.5 months [30]. The response rate in our study was lower and decreased in the long-term follow-up, but rituximab was used once again almost as the last pharmacological resource.

Rituximab off-label use was commonly requested in kidney diseases such as glomerulonephritis, the membranous glomerulonephritis being the most frequent. We have observed good short-term and long-term results as far as proteinuria is concerned in these patients, although some of them received additional doses of rituximab to maintain a lasting response. In a systematic review of case reports and case series that included 85 patients diagnosed with membranous glomerulonephritis treated with rituximab, a 15 to $20 \%$ rate of complete remission and a 35 to $40 \%$ rate of partial remission were reported [31]. Now some clinical trials have been completed, but no results have been published to date.

Rituximab is very expensive and the treatment of all cases in our study had a significant cost as has been reported in other studies [13, 14]. Cost is a matter of controversy in off-label drug uses, because the available evidence of cases is usually scarce and their cost-benefit rate is often uncertain. The use of off-label drugs can be controversial. Health managers, doctors, the pharmaceutical industry and patients can have different expectations, and we need to make reliable decisions. Physicians believe that their use may be justified by the poor 
prognosis of patients and the inability of achieving good results with alternative treatments, and patients want to be cured. The pharmaceutical industry is interested in promoting the use of their drugs as much as possible, even in offlabel indications [32]. Health managers are reluctant to reimburse the cost of those treatments with such little scientific evidence supporting its use [33]. The off-label use of costly drugs requires a careful evaluation of cases and reasonable expectations regarding clinical outcome. Clinical trials should be done to assess the efficacy of rituximab in off-label indications, but funding trials in rare diseases can be difficult. Meanwhile, it would seem reasonable to treat particularly severe cases unresponsive to other therapy with a possibly effective drug albeit evidence is incomplete. In the absence of randomised clinical trials, the results of prospective registries of patients treated in these conditions or observational studies similar to this present may be useful.

This study has some limitations. Firstly, it is an observational study with a retrospective design and without a control group. Therefore the results might be biased. Secondly, we included a heterogeneous group of diseases with few cases in each group and, consequently, we have limited information. Finally, only two centres were included in the study. As a result, our findings could not be extrapolated to other hospitals in other geographical areas. However, as a main strength, this is the largest study in which evidence-based indications, patients' outcomes and cost of different off-label use of rituximab has been assessed. Moreover, in our study the outcome survey was longer than in others, and the centres participating were two large tertiary teaching hospitals, with all medical and surgical specialities, and high a level of complexity.

In conclusion, indications for the off-label use of rituximab were variable, although haematological, kidney and systemic connective tissue diseases were the main indications. Available evidence for rituximab in most of these settings was low, but there were ongoing clinical trials assessing its efficacy. In general, short-term response was quite good, bearing in mind that patients were usually refractory to other treatments, and almost half of them maintained long-term response. In the absence of strong evidence, and taking into account that 
clinical trials can be difficult in some rare diseases, data from prospective registers and observational studies of patients treated with off-label use of rituximab may provide useful information to improve prescribing decisions in clinical practice. 


\section{REFERENCES}

1. Real Decreto $1015 / 2009$, de 19 de junio, por el que se regula la disponibilidad de medicamentos en situaciones especiales. Boletín Oficial del Estado. Núm. 174 Lunes 20 de julio de 2009 Sec. I. Pág. 60904.

2. CatSalut (2010). Instrucció 05/2010. Utilització de medicaments autoritzats en condicions diferents de les establertes en la fitxa tècnica. http://www10.gencat.cat/catsalut/archivos/instruccions/instruccio 05 2010.pdf

3. Alerany C, Agustí A, Danés I, Martínez J, Fernández J, Bosch JA (2010). Com adaptar-nos a la nova normativa d'utilització de medicaments en situacions especials: un exemple d'iniciativa. e-farma;12.

http://www10.gencat.net/catsalut/rsb/farmacia/efarma/articles/adaptacio nova normativa vhebron.pdf

4. Weiner GJ (2010). Rituximab: mechanism of action. Semin Hematol 47:11523.

5. European Medicines Agency. Mabthera: EPAR-Product information. http://www.ema.europa.eu/docs/en GB/document library/EPAR Product Information/human/000165/WC500025821.pdf

6. Gillis JZ, Dall'era M, Gross A, Yazdany J, Davis J (2007). Six refractory lupus patients treated with rituximab: a case series. Arthritis Rheum 57:538-42.

7. Melander $C$, Sallée $M$, Trolliet $P$, Candon $S$, Belenfant $X$, Daugas $E$, Rémy $P$, Zarrouk V, Pillebout E, Jacquot C, Boffa JJ, Karras A, Masse V, Lesavre P, Elie $C$, Brocheriou I, Knebelmann B, Noël LH, Fakhouri F (2009). Rituximab in severe lupus nephritis: early B-cell depletion affects long-term renal outcome. Clin J Am Soc Nephrol 4:579-87.

8. Díaz-Lagares C, Croca S, Sangle S, Vital EM, Catapano F, MartínezBerriotxoa A, García-Hernández F, Callejas-Rubio JL, Rascón J, D'Cruz D, Jayne D, Ruiz-Irastorza G, Emery P, Isenberg D, Ramos-Casals M, Khamashta MA; UK-BIOGEAS Registry (2012). Efficacy of rituximab in 164 patients with biopsy-proven lupus nephritis: pooled data from European cohorts. Autoimmun Rev 11:357-64.

9. Terrier B, Amoura Z, Ravaud P, Hachulla E, Jouenne R, Combe B, Bonnet C, Cacoub P, Cantagrel A, de Bandt M, Fain O, Fautrel B, Gaudin P, Godeau B, Harlé JR, Hot A, Kahn JE, Lambotte O, Larroche C, Léone J, Meyer O, PallotPrades B, Pertuiset E, Quartier P, Schaerverbeke T, Sibilia J, Somogyi A, Soubrier M, Vignon E, Bader-Meunier B, Mariette X, Gottenberg JE; Club Rhumatismes et Inflammation (2010). Safety and efficacy of rituximab in 
systemic lupus erythematosus: results from 136 patients from the French Autolmmunity and Rituximab registry. Arthritis Rheum 62:2458-66.

10. Trachana M, Koutsonikoli A, Farmaki E, Printza N, Tzimouli V, Papachristou $F$ (2011). Safety and efficacy of Rituximab in refractory pediatric systemic lupus erythematosus nephritis: a single-center experience of Northern Greece. Rheumatol Int. doi: 10.1007/s00296-011-2239-6.

11. Ramos-Casals M, Soto MJ, Cuadrado MJ, Khamashta MA (2009). Rituximab in systemic lupus erythematosus: A systematic review of off-label use in 188 cases. Lupus 18:767-76.

12. Ramos-Casals $M$, García-Hernández FJ, de Ramón E, Callejas JL, Martínez-Berriotxoa A, Pallarés L, Caminal-Montero L, Selva-O'Callaghan A, Oristrell J, Hidalgo C, Pérez-Alvarez R, Micó ML, Medrano F, Gómez de la Torre R, Díaz-Lagares C, Camps M, Ortego N, Sánchez-Román J; BIOGEAS Study Group (2010). Off-label use of rituximab in 196 patients with severe, refractory systemic autoimmune diseases. Clin Exp Rheumatol 28:468-76.

13. Butterly SJ, Pillans P, Horn B, Miles R, Sturtevant J (2010). Off-label use of rituximab in a tertiary Queensland hospital. Int Intern Med J 40:443-52.

14. Van Allen EM, Miyake T, Gunn N, Behler CM, Kohlwes J (2011). Off-label use of rituximab in a multipayer insurance system. J Oncol Pract 7:76-9.

15. Conde García MC, Fernández Feijoo MA, Calleja Hernández MA (2009). Estudio de adecuación a la ficha técnica, efectividad, seguridad y coste del rituximab en un hospital de tercer nivel. Farm Hosp 33:305-11.

16. Cheson BD, Pfistner B, Juweid ME, Gascoyne RD, Specht L, Horning SJ, Coiffier B, Fisher RI, Hagenbeek A, Zucca E, Rosen ST, Stroobants S, Lister TA, Hoppe RT, Dreyling M, Tobinai K, Vose JM, Connors JM, Federico M, Diehl V (2007). Revised response criteria for malignant lymphoma. J Clin Oncol 25:579-86.

17. Oxford Centre for Evidence-based Medicine - Levels of Evidence (March 2009). http://www.cebm.net/?o=1025. Accessed 12 September 2012.

18. US National Institutes of Health. Clinicaltrials.gov.

http://clinicaltrials.gov/ct2/home Accessed 12 September 2012.

19. Schulz H, Bohlius JF, Trelle S, Skoetz N, Reiser M, Kober T, Schwarzer G, Herold M, Dreyling M, Hallek M, Engert A (2007). Immunochemotherapy with rituximab and overall survival in patients with indolent or mantle cell lymphoma: a systematic review and meta-analysis. J Natl Cancer Inst 99:706-14. 
20. Robak T, Dmoszynska A, Solal-Céligny P, Zyuzgin I, Ganly PS, Dartigeas C, Afanasiev BV, Larratt L, Geisler CH, Montillo M, Zyuzgin I, Ganly PS, Dartigeas C, Rosta A, Maurer J, Mendila M, Saville MW, Valente N, Wenger MK, Moiseev SI (2010). Rituximab plus fludarabine and cyclophosphamide prolongs progression-free survival compared with fludarabine and cyclophosphamide alone in previously treated chronic lymphocytic leukemia. J Clin Oncol 28:1756-65.

21. Coiffier B, Lepage E, Briere J, Herbrecht R, Tilly H, Bouabdallah R, Morel P, Van Den Neste E, Salles G, Gaulard P, Reyes F, Lederlin P, Gisselbrecht C (2002). CHOP chemotherapy plus rituximab compared with $\mathrm{CHOP}$ alone in elderly patients with diffuse large-B-cell lymphoma. N Engl J Med 346:235-42.

22. Feugier $P$, Van Hoof $A$, Sebban $C$, Solal-Celigny $P$, Bouabdallah R, Fermé C, Christian B, Lepage E, Tilly H, Morschhauser F, Gaulard P, Salles G, Bosly A, Gisselbrecht C, Reyes F, Coiffier B (2005). Long-term results of the R-CHOP study in the treatment of elderly patients with diffuse large B-cell lymphoma: a study by the Groupe d'Etude des Lymphomes de l'Adulte. J Clin Oncol 23:411726.

23. Pfreundschuh M, Trümper L, Osterborg A, Pettengell R, Trneny M, Imrie K, Ma D, Gill D, Walewski J, Zinzani PL, Stahel R, Kvaloy S, Shpilberg O, Jaeger U, Hansen M, Lehtinen T, López-Guillermo A, Corrado C, Scheliga A, Milpied N, Mendila M, Rashford M, Kuhnt E, Loeffler M; MabThera International Trial Group (2006). CHOP-like chemotherapy plus rituximab versus CHOP-like chemotherapy alone in young patients with good-prognosis diffuse large-B-cell lymphoma: a randomised controlled trial by the MabThera International Trial (MInT) Group. Lancet Oncol 7:379-91.

24. Kluin-Nelemans HC, Hoster E, Hermine O, Walewski J, Trneny M, Geisler $\mathrm{CH}$, Stilgenbauer S, Thieblemont C, Vehling-Kaiser U, Doorduijn JK, Coiffier B, Forstpointner R, Tilly H, Kanz L, Feugier P, Szymczyk M, Hallek M, Kremers S, Lepeu G, Sanhes L, Zijlstra JM, Bouabdallah R, Lugtenburg PJ, Macro M, Pfreundschuh M, Procházka V, Di Raimondo F, Ribrag V, Uppenkamp M, André M, Klapper W, Hiddemann W, Unterhalt M, Dreyling MH (2012). Treatment of older patients with mantle-cell lymphoma. N Engl J Med 367:52031.

25. Merrill JT, Neuwelt CM, Wallace DJ, Shanahan JC, Latinis KM, Oates JC, Utset TO, Gordon C, Isenberg DA, Hsieh HJ, Zhang D, Brunetta PG (2010). Efficacy and safety of rituximab in moderately-to-severely active systemic lupus erythematosus: the randomized, double-blind, phase II/III systemic lupus erythematosus evaluation of rituximab trial. Arthritis Rheum 62:222-33.

26. Narváez J, Ríos-Rodríguez V, de la Fuente D, Estrada P, López-Vives L, Gómez-Vaquero C, Nolla JM (2011). Rituximab therapy in refractory neuropsychiatric lupus: current clinical evidence. Semin Arthritis Rheum 41:36472. 
27. Rovin BH, Furie R, Latinis K, Looney RJ, Fervenza FC, Sanchez-Guerrero J, Maciuca R, Zhang D, Garg JP, Brunetta P, Appel G; LUNAR Investigator Group (2012). Efficacy and safety of rituximab in patients with active proliferative lupus nephritis: the Lupus Nephritis Assessment with Rituximab study. Arthritis Rheum 64:1215-26.

28. Lightstone $L$ (2012). The landscape after LUNAR: Rituximab's crater-filled path. Arthritis Rheum 64:962-5.

29. Zaja F, Baccarani M, Mazza P, Bocchia M, Gugliotta L, Zaccaria A, Vianelli N, Defina M, Tieghi A, Amadori S, Campagna S, Ferrara F, Angelucci E, Usala E, Cantoni S, Visani G, Fornaro A, Rizzi R, De Stefano V, Casulli F, Battista ML, Isola M, Soldano F, Gamba E, Fanin R (2010). Dexamethasone plus rituximab yields higher sustained response rates than dexamethasone monotherapy in adults with primary immune thrombocytopenia. Blood 115:2755-62.

30. Arnold DM, Dentali F, Crowther MA, Meyer RM, Cook RJ, Sigouin C, Fraser GA, Lim W, Kelton JG (2007). Systematic review: efficacy and safety of rituximab for adults with idiopathic thrombocytopenic purpura. Ann Intern Med 146:25-33.

31. Bomback AS, Derebail VK, McGregor JG, Kshirsagar AV, Falk RJ, Nachman PH (2009). Rituximab therapy for membranous nephropathy: a systematic review. Clin J Am Soc Nephrol 4:734-44.

31. Hampton T (2007). Experts weigh in on promotion, prescription of off-label drugs. JAMA 297:683-4.

33. American Cancer Society. Off-label drug use.

http://www.cancer.org/Treatment/TreatmentsandSideEffects/TreatmentTypes/C hemotherapy/off-label-drug-use. Accessed 11 November 2012. 
Table 1. Indications for rituximab off-label use and available evidence when it was requested

\begin{tabular}{|c|c|c|c|}
\hline Indication & n (\%) & $\begin{array}{l}\text { Level of } \\
\text { evidence }\end{array}$ & $\begin{array}{l}\text { Ongoing } \\
\text { studies }\end{array}$ \\
\hline \multicolumn{4}{|l|}{ Systemic lupus erythematosus } \\
\hline - $\quad$ Lupus nephritis & $18(17.8)$ & $2 b$ & Phase 3 \\
\hline - $\quad$ Systemic lupus erythematosus (without nephritis) & $8(7.9)$ & $2 b$ & Phase 3 \\
\hline Chronic lymphocytic leukemia $^{a}$ & $11(10.9)$ & $2 a$ & Phase 3 \\
\hline Idiopathic thrombocytopenic purpura & $10(9.9)$ & $2 b$ & Phase 3 \\
\hline Large B-cell non-Hodgkin lymphoma $^{a}$ & $7(6.9)$ & $2 b$ & Phase 3 \\
\hline Membranous glomerulonephritis & $7(6.9)$ & $2 b$ & Phase 3 \\
\hline Membranoproliferative/mesangiocapillary glomerulonephritis & $6(5.9)$ & 4 & Phase 2 \\
\hline Mantle-cell non-Hodgkin lymphoma & $6(5.9)$ & $1 \mathrm{a}$ & Phase 3 \\
\hline Neuromyelitis optica & $5(5.0)$ & 4 & Phase 1 \\
\hline Follicular non-Hodgkin lymphoma ${ }^{a}$ & $4(4.0)$ & $1 a$ & Phase 3 \\
\hline Minimal change glomerulonephritis & $3(3.0)$ & 4 & Phase 2 \\
\hline Desensitization anti-HLA before transplantation & $2(2.0)$ & $2 b$ & Phase 2 \\
\hline Marginal zone non-Hodgkin lymphoma & $2(2.0)$ & 4 & Phase 2 \\
\hline Thrombotic thrombocytopenic purpura & $2(2.0)$ & 4 & Phase 3 \\
\hline Other $^{b}$ & $10(9.9)$ & $4^{\mathrm{c}}$ & d \\
\hline Total & 101 & $(100)$ & \\
\hline
\end{tabular}

${ }^{a}$ Cases of chronic lymphocytic leukemia, large B-cell non-Hodgkin lymphoma, and follicular non-Hodgkin lymphoma included in the study were off-label conditions when rituximab use was requested.

${ }^{b}$ Included two cases of marginal zone lymphoma of different localization (one conjunctival and other splenic) and one case of dermatomyositis, multi-centric Castleman's disease, fibrillary glomerulonephritis, focal-segmental glomerulonephritis, myelopathy of unknown cause, antiphospholipid syndrome, small cell non-Hodgkin lymphoma, and myasthenia gravis indications.

${ }^{c}$ Level 4 for all the other conditions, but level 5 in myelopathy of unknown cause, and level $2 \mathrm{~b}$ in small cell non-Hodgkin lymphoma.

${ }^{\mathrm{d}}$ Ongoing phase 2 clinical trials were available for dermatomyositis, focal-segmental glomerulonephritis, splenic marginal zone lymphoma, antiphospholipid syndrome, and myasthenia gravis, and ongoing phase 3 clinical trials for small cell non-Hodgkin lymphoma. No ongoing clinical trials were identified for conjunctival marginal zone lymphoma, multi-centric Castleman's disease, fibrillary glomerulonephritis, and myelopathy of unknown cause, 
Table 2. Observed outcome according to the disease

\begin{tabular}{|c|c|c|c|c|c|c|c|c|}
\hline \multirow[b]{2}{*}{ Indication ${ }^{\mathrm{b}}$} & \multicolumn{4}{|c|}{ Short-term ${ }^{a}$} & \multicolumn{4}{|c|}{ Long-term ${ }^{a}$} \\
\hline & $\begin{array}{c}\text { NR } \\
\text { n (\%) }\end{array}$ & $\begin{array}{c}\text { PR } \\
\text { n (\%) }\end{array}$ & $\begin{array}{c}\text { CR } \\
\text { n (\%) }\end{array}$ & Total* $^{*}$ & $\begin{array}{c}\text { NR } \\
\text { n (\%) }\end{array}$ & $\begin{array}{c}\text { PR } \\
\text { n (\%) }\end{array}$ & $\begin{array}{c}\text { CR } \\
\text { n (\%) }\end{array}$ & Total\# \\
\hline \multicolumn{9}{|l|}{ Systemic lupus erythematosus } \\
\hline - Lupus nephritis & $4(22.2)$ & $5(27.8)$ & $9(50)$ & $18(100)$ & $5(27.8)$ & $4(22.2)$ & $9(50)$ & $18(100)$ \\
\hline - $\quad$ Systemic lupus erythematosus (without nephritis) & 0 & $4(50)$ & $4(50)$ & $8(100)$ & $3(37.5)$ & $3(37.5)$ & $2(25)$ & $8(100)$ \\
\hline Chronic lymphocytic leukemia & $4(36.4)$ & $3(27,2)$ & $4(36.4)$ & $11(100)$ & $8(72.7)$ & $1(9.1)$ & $2(18.2)$ & $11(100)$ \\
\hline Idiopathic thrombocytopenic purpura & $3(50)$ & $1(16.7)$ & $2(33.3)$ & $6(100)$ & $4(66.7)$ & 0 & $2(33.3)$ & $6(100)$ \\
\hline Mantle-cell non-Hodgkin lymphoma & $1(16.7)$ & $3(50)$ & $2(33.3)$ & $6(100)$ & $6(100)$ & 0 & 0 & $6(100)$ \\
\hline Membranoproliferative/mesangiocapillary glomerulonephris. & $2(33.3)$ & $1(16.7)$ & $3(50)$ & $6(100)$ & $3(50)$ & 0 & $3(50)$ & $6(100)$ \\
\hline Membranous glomerulonephritis & 0 & $4(66.7)$ & $2(33.3)$ & $6(100)$ & $1(16,7)$ & $3(50)$ & $2(33.3)$ & $6(100)$ \\
\hline Large B-cell non-Hodgkin lymphoma & $3(60)$ & 0 & $2(40)$ & $5(100)$ & $4(80)$ & 0 & $1(20)$ & $5(100)$ \\
\hline Follicular non-Hodgkin lymphoma & 0 & $2(50)$ & $2(50)$ & $4(100)$ & $1(25)$ & $2(50)$ & $1(25)$ & $4(100)$ \\
\hline Neuromyelitis optica & $2(50)$ & $2(50)$ & 0 & $4(100)$ & $2(50)$ & $2(50)$ & 0 & $4(100)$ \\
\hline Minimal change glomerulonephritis & $1(33.3)$ & $2(66.7)$ & 0 & $3(100)$ & $1(33.3)$ & $1(33.3)$ & $1(33.3)$ & $3(100)$ \\
\hline Desensitization anti-HLA before transplantation & 0 & 0 & $2(100)$ & $2(100)$ & 0 & 0 & $2(100)$ & $2(100)$ \\
\hline Thrombotic thrombocytopenic purpura & 0 & 0 & $2(100)$ & $2(100)$ & 0 & 0 & $2(100)$ & $2(100)$ \\
\hline Other ${ }^{c}$ & $7(63.6)$ & $3(27.3)$ & $1(9.1)$ & $11(100)$ & $9(90)$ & $1(10)$ & $1(10)$ & $11(100)$ \\
\hline
\end{tabular}

a Short-term after a median period of 3 months (IQR 2-4), and long-term after a median of 23 months (IQR 12-30).

NR: No response; PR: Partial response; CR: Complete response.

${ }^{b}$ Patients to whom rituximab was not administered or lost in follow-up have been excluded: Idiopathic thrombocytopenic purpura (4), large B-cell non-Hodgkin lymphoma (2), cutaneous marginal zone non-Hodgkin lymphoma (1), membranous glomerulonephritis (1), and neuromyelitis optica (1).

${ }^{\mathrm{c}}$ Short-term response for other diseases: Dermatomyositis, multi-centric Castleman's disease, fibrillary GN, focal-segmental GN, conjunctival marginal zone lymphoma, myelopathy (unknown cause), and antiphospholipid syndrome (NR); small cell non-Hodgkin lymphoma, splenic marginal zone lymphoma, and myasthenia gravis (PR); cutaneous marginal zone non-Hodgkin lymphoma (CR). 
Table 3. Demographics and clinical course of patients with diseases often treated with rituximab

\begin{tabular}{|c|c|c|c|c|c|c|c|c|}
\hline $\begin{array}{l}\text { Indication (number of } \\
\text { patients treated) }\end{array}$ & $\begin{array}{l}\text { Age } \\
\text { [median } \\
(I Q R)] \\
\text { Sex }\end{array}$ & $\begin{array}{c}\text { Main clinical } \\
\text { and/or } \\
\text { biochemical } \\
\text { characteristic } \\
\text { before rituximab } \\
\text { treatment }\end{array}$ & Previous treatments & $\begin{array}{l}\text { Rituximab } \\
\text { regimen }\end{array}$ & $\begin{array}{l}\text { Time of } \\
\text { short- } \\
\text { term } \\
\text { follow } \\
\text { up } \\
\text { [median } \\
\text { (IQR)] }\end{array}$ & $\begin{array}{l}\text { Definition of } \\
\text { outcome }\end{array}$ & $\begin{array}{l}\text { Median } \\
\text { time of } \\
\text { long-term } \\
\text { follow up } \\
\text { [median } \\
\text { (IQR)] }\end{array}$ & $\begin{array}{l}\text { Last visit: } \\
\text { patients with } \\
\text { response }[\mathrm{n}(\%)] \text {, and } \\
\text { their treatment }\end{array}$ \\
\hline $\begin{array}{l}\text { Lupus nephritis } \\
(\mathrm{n}=18)^{\mathrm{b}}\end{array}$ & $\begin{array}{l}30 \text { y } \\
(25-36) \\
67 \% \mathrm{~F}\end{array}$ & $\begin{array}{l}24 \text { h proteinuria } \\
>2.5 \mathrm{~g}(\geq 5 \mathrm{~g} \text { in } 9 \\
\text { cases) }\end{array}$ & $\begin{array}{l}\text { Refractory to } \\
\text { immunosuppressive agents } \\
\text { (including corticosteroids): } \\
\text { - } \geq 3 \text { drugs: } 8 \text { patients. } \\
\text { - } 2 \text { drugs: } 5 \text { patients. } \\
\text { All patients had received } \\
\text { mycophenolate. }\end{array}$ & $\begin{array}{l}1 \mathrm{~g} \text { IV } 2 \text { weeks apart } \\
\text { (95\% of cases). }\end{array}$ & $\begin{array}{l}4 \mathrm{mo} \\
(2.5-6)\end{array}$ & $\begin{array}{l}\text { CR: proteinuria } \leq \\
500 \mathrm{mg} / 24 \mathrm{~h} . \\
\text { PR: improvement } \\
\geq 50 \% \text { of } 24 \mathrm{~h} \\
\text { proteinuria. }\end{array}$ & $\begin{array}{l}21 \mathrm{mo} \\
(15.5- \\
25.5)\end{array}$ & $\begin{array}{l}13(72.2 \%) \text {. } \\
\text { Treatment with } \\
\text { immunosuppressive } \\
\text { agents (one of them } \\
\text { was always } \\
\text { mycophenolate): } \\
\text { - } 3 \text { drugs: } 1 \text { patient } \\
\text { - } 2 \text { drugs: } 8 \text { patients (1 } \\
\text { of them also with } \\
\text { additional doses of } \\
\text { rituximab). } \\
\text { - } 1 \text { drug (2 patients) } \\
\text { - No treatment (2) }\end{array}$ \\
\hline $\begin{array}{l}\text { Systhemic lupus } \\
\text { erythematosus } \\
\text { without nephritis } \\
(n=8)\end{array}$ & $\begin{array}{l}43 y \\
(33.5-53) . \\
87.5 \% \mathrm{~F}\end{array}$ & $\begin{array}{l}\text { SLEDAI >6 in } 5 \\
\text { cases. }\end{array}$ & $\begin{array}{l}\text { All patients treated with at } \\
\text { least } 3 \text { immunosuppressive } \\
\text { agents ( } 62.5 \% \text { with } 4 \text { or } \\
\text { more). }\end{array}$ & $1 \mathrm{~g}$ IV 2 weeks apart. & $\begin{array}{l}4 \mathrm{mo} \\
(2-4)\end{array}$ & $\begin{array}{l}\text { CR: clinical } \\
\text { remission. } \\
\text { PR: improvement }\end{array}$ & $\begin{array}{l}26 \mathrm{mo} \\
(24.5-35)\end{array}$ & $\begin{array}{l}5(62.5 \%) \\
\text { - Treatment with } \\
\text { corticosteroids and }\end{array}$ \\
\hline
\end{tabular}




\begin{tabular}{|c|c|c|c|c|c|c|c|c|}
\hline & & & & & & $\geq 50 \%$ of SLEDAI. & & $\begin{array}{l}\text { another } \\
\text { immunosuppressive } \\
\text { agent }\end{array}$ \\
\hline $\begin{array}{l}\text { Chronic lymphocytic } \\
\text { leukemia }(n=11)\end{array}$ & $\begin{array}{l}70 \mathrm{y} \\
(57-77.5) . \\
54.5 \% \mathrm{M}\end{array}$ & $\begin{array}{l}\text { All cases with } \\
\text { relapsed/refractory } \\
\text { disease . } 63.6 \% \\
\text { high risk and } 36.4 \% \\
\text { intermediate risk } \\
\text { disease }^{c} \text {. }\end{array}$ & $\begin{array}{l}\text { - } 9 \text { patients previously } \\
\text { treated with } \geq 2 \\
\text { chemotherapeutic } \\
\text { regimens. }\end{array}$ & $\begin{array}{l}375 \mathrm{mg} / \mathrm{m}^{2} \text { (1-6 } \\
\text { cycles), with other } \\
\text { drugs (fludarabine, } \\
\text { mitoxantrone, } \\
\text { bendamustin, } \\
\text { cyclophosphamide, } \\
\text { and/or pentostatin). }\end{array}$ & $\begin{array}{l}3 \mathrm{mo} \\
(2-4)\end{array}$ & $\begin{array}{l}\text { CR: no symptoms } \\
\text { and normalization } \\
\text { of lymph nodes, } \\
\text { spleen, liver and } \\
\text { biochemics. } \\
\text { PR: decrease of } \\
\text { node size } \geq 50 \% \text {, } \\
\text { and blood count } \\
\text { improvement. }\end{array}$ & $\begin{array}{l}11 \mathrm{mo} \\
(8-21)\end{array}$ & $\begin{array}{l}3(27.3 \%) \\
\text { - Intravenous } \\
\text { immunoglobulin (1) } \\
\text { - } 2 \text { patients with no } \\
\text { treatment, one of them } \\
\text { underwent an } \\
\text { hematopoietic stem } \\
\text { cell transplantation }\end{array}$ \\
\hline $\begin{array}{l}\text { Mantle-cell non- } \\
\text { Hodgkin Iymphoma } \\
(n=6)\end{array}$ & $\begin{array}{l}70.5 \text { y } \\
(61-77) . \\
83 \% \mathrm{M}\end{array}$ & $\begin{array}{l}\text { Lymphadenopathies } \\
\text { ( } \pm \text { extranodal } \\
\text { involvement). }\end{array}$ & $\begin{array}{l}\text { - } 5 \text { patients ( } 83.3 \%) \\
\text { previously treated with R- } \\
\text { EPOCH ( } 2 \text { of them also } \\
\text { with other regimens) } \\
\text { - Cyclophosphamide, } \\
\text { vincristine, and } \\
\text { dexamethasone ( } 1 \text { patient). }\end{array}$ & $\begin{array}{l}375 \mathrm{mg} / \mathrm{m}^{2}(3-8 \\
\text { cycles). }\end{array}$ & $\begin{array}{l}6 \mathrm{mo} \\
(3.5-7.5)\end{array}$ & $\begin{array}{l}\text { CR: } \\
\text { Disappearance of } \\
\text { all evidence of } \\
\text { disease. } \\
\text { PR: Regression of } \\
\text { measurable } \\
\text { disease, decrease } \\
\text { of lymph node size } \\
\geq 50 \% \text {. }\end{array}$ & $\begin{array}{l}13.5 \mathrm{mo} \\
(6-25)\end{array}$ & \\
\hline $\begin{array}{l}\text { Idiopathic } \\
\text { thrombocytopenic } \\
\text { purpura }(n=6)\end{array}$ & $\begin{array}{l}73 \text { y } \\
(41-78) \\
67 \% \mathrm{~F}\end{array}$ & $\begin{array}{l}\text { Platelet count } \\
\leq 20 \times 10^{9} / \mathrm{L}(66.7 \% \\
\text { of patients }<10 \times \\
\left.10^{9} / \mathrm{L}\right) .\end{array}$ & $\begin{array}{l}\text { All } 6 \text { patients treated with } \\
\text { corticosteroids, } 5 \text { of them } \\
\text { also with immunoglobulins } \\
\text { and } 1 \text { with plasmapheresis. }\end{array}$ & $\begin{array}{l}1 \mathrm{~g} \text { IV } 2 \text { weeks apart } \\
\text { (50\% of cases) and } \\
375 \mathrm{mg} / \mathrm{m}^{2} \text { weekly ( } \\
4 \text { doses) }\end{array}$ & $\begin{array}{l}1,25 \mathrm{mo} \\
(0.5-2)\end{array}$ & $\begin{array}{l}\text { CR: platelet count } \\
>150 \times 10^{9} / \mathrm{L} . \\
\text { PR: platelet count } \\
>50 \times 10^{9} / \mathrm{L} .\end{array}$ & $\begin{array}{l}29 \mathrm{mo} \\
(22-41.5)\end{array}$ & $\begin{array}{l}2(33.3 \%) \\
\text { - Intravenous } \\
\text { immunoglobulin (1) }\end{array}$ \\
\hline
\end{tabular}




\begin{tabular}{|c|c|c|c|c|c|c|c|c|}
\hline & & & $\begin{array}{l}\text { Another } \\
\text { immunosuppressive agent } \\
\text { in } 3 \text { cases. }\end{array}$ & & & & & - No treatment (1) \\
\hline $\begin{array}{l}\text { Membranous } \\
\text { glomerulonephritis } \\
(n=6)\end{array}$ & $\begin{array}{l}50 y \\
(41-60) . \\
67 \% M\end{array}$ & $\begin{array}{l}24 \mathrm{~h} \text { proteinuria (> } 3 \\
\mathrm{~g} \text { in } 5 \text { cases). }\end{array}$ & $\begin{array}{l}\text { Tacrolimus and } \\
\text { corticosteroids } \pm \text { ACE } \\
\text { inhibitors, furosemide. }\end{array}$ & $\begin{array}{l}1 \mathrm{~g} \text { IV } 2 \text { weeks apart } \\
(66.6 \% \text { of cases). }\end{array}$ & $\begin{array}{l}3 \mathrm{mo} \\
(2-3)\end{array}$ & $\begin{array}{l}\text { CR: proteinuria } \leq \\
500 \mathrm{mg} / 24 \mathrm{~h} . \\
\text { PR: improvement } \\
\geq 50 \% \text { of } 24 \mathrm{~h} \\
\text { proteinuria. }\end{array}$ & $\begin{array}{l}25 \mathrm{mo} \\
(20-26)\end{array}$ & $\begin{array}{l}5 \text { (83.3\%). } \\
\text { - Additional infusions of } \\
\text { rituximab: } 2 \text { patients } \\
\text { (one of them also with } \\
\text { tacrolimus and } \\
\text { prednisone) } \\
\text { - Cyclophosphamide } \\
\text { and corticosteroids (1) } \\
\text { - No treatment (2) }\end{array}$ \\
\hline $\begin{array}{l}\text { Membranoproliferativ } \\
\text { e/mesangiocapillary } \\
\text { glomerulonephritis } \\
(n=6)\end{array}$ & $\begin{array}{l}50.5 \mathrm{y} \\
(36-56) \\
67 \% \mathrm{~F}\end{array}$ & $\begin{array}{l}24 \mathrm{~h} \text { proteinuria( }>5 \\
\mathrm{~g} \text { in } 4 \text { cases). }\end{array}$ & $\begin{array}{l}5 \text { patients treated with } \geq 2 \\
\text { immunosuppressive agents } \\
( \pm \text { ACE inhibitors, } \\
\text { furosemide). Enalapril }(1) \text {. }\end{array}$ & $\begin{array}{l}375 \mathrm{mg} / \mathrm{m}^{2} \text { weekly ( } \\
4 \text { doses); ( } 67 \% \text { of } \\
\text { cases). }\end{array}$ & $2 \mathrm{mo}$ & $\begin{array}{l}\text { CR: proteinuria } \leq \\
500 \mathrm{mg} / 24 \mathrm{~h} . \\
\text { PR: improvement } \\
\geq 50 \% \text { of } 24 \mathrm{~h} \\
\text { proteinuria. }\end{array}$ & $\begin{array}{l}38 \mathrm{mo} \\
(38-42)\end{array}$ & $\begin{array}{l}3(50 \%) \\
\text { - Furosemide, } \\
\text { telmisartan and } \\
\text { doxazosin (1) } \\
\text { - No treatment (2) }\end{array}$ \\
\hline $\begin{array}{l}\text { Large B-cell non- } \\
\text { Hodgkin Iymphoma } \\
(n=5)\end{array}$ & $\begin{array}{l}52 \text { y } \\
(57-62) \\
60 \% \mathrm{M}\end{array}$ & $\begin{array}{l}\text { Lymphadenopathies } \\
\text { ( } \pm \text { extranodal } \\
\text { involvement). }\end{array}$ & $\begin{array}{l}\text { Relapsed/refractory } \\
\text { disease in all patients, } 60 \% \\
\text { previously treated with } \geq 3 \\
\text { chemotherapeutic } \\
\text { regimens. }\end{array}$ & $\begin{array}{l}375 \mathrm{mg} / \mathrm{m}^{2} \text { (1-6 } \\
\text { cycles), with } \\
\text { gemcitabine and } \\
\text { oxaliplatin (and } \\
\text { ifosfamide in } 1 \\
\text { case). }\end{array}$ & $\begin{array}{l}3 \mathrm{mo} \\
(2-3)\end{array}$ & $\begin{array}{l}\text { CR: } \\
\text { Disappearance of } \\
\text { all evidence of } \\
\text { disease. } \\
\text { PR: Regression of } \\
\text { measurable } \\
\text { disease, decrease } \\
\text { of lymph node size }\end{array}$ & $\begin{array}{l}9 \mathrm{mo} \\
(8-10)\end{array}$ & $\begin{array}{l}1(20 \%) \\
\text { - No treatment }\end{array}$ \\
\hline
\end{tabular}




\begin{tabular}{|c|c|c|c|c|c|c|c|c|}
\hline & & & & & & $\geq 50 \%$ & & \\
\hline $\begin{array}{l}\text { Follicular non- } \\
\text { Hodgkin Iymphoma } \\
(n=4)\end{array}$ & $\begin{array}{l}77 \text { y } \\
(60.5-78) \\
50 \% \mathrm{M} / \\
50 \% \mathrm{~F}\end{array}$ & $\begin{array}{l}\text { Lymphadenopathies } \\
\text { ( } \pm \text { extranodal } \\
\text { involvement). }\end{array}$ & $\begin{array}{l}\text { Relapsed/refractory } \\
\text { disease in all patients, } 75 \% \\
\text { previously treated with } \geq 3 \\
\text { chemotherapeutic } \\
\text { regimens. }\end{array}$ & $\begin{array}{l}375 \mathrm{mg} / \mathrm{m}^{2}(2-6 \\
\text { cycles), with } \\
\text { bendamustin (and } \\
\text { mitoxantrone in } 1 \\
\text { case). }\end{array}$ & $\begin{array}{l}4.5 \mathrm{mo} \\
(3-6)\end{array}$ & $\begin{array}{l}\text { CR: } \\
\text { Disappearance of } \\
\text { all evidence of } \\
\text { disease. } \\
\text { PR: Regression of } \\
\text { measurable } \\
\text { disease, decrease } \\
\text { of lymph node size } \\
\geq 50 \% \text {. }\end{array}$ & $\begin{array}{l}26.5 \\
(12.5-33)\end{array}$ & $\begin{array}{l}3(75 \%) \\
\text { - Maintenance therapy } \\
\text { with rituximab (1) } \\
\text { - No treatment (2) }\end{array}$ \\
\hline $\begin{array}{l}\text { Neuromyelitis optica } \\
(n=4)\end{array}$ & $\begin{array}{l}47 \mathrm{y} \\
(38-52) \\
75 \% \mathrm{~F}\end{array}$ & $\begin{array}{l}\text { Refractory } \\
\text { neuromyelitis. }\end{array}$ & $\begin{array}{l}\text { - } 3 \text { patients }(75 \%) \text { received } \\
\text { before } 3-4 \text { treatments } \\
\text { (immunosuppressive and } \\
\text { immunomodulatory } \\
\text { agents). } \\
\text { - Interferon (1). }\end{array}$ & $\begin{array}{l}375 \mathrm{mg} / \mathrm{m}^{2} \text { weekly ( } \\
3-4 \text { doses); (50\% of } \\
\text { cases). }\end{array}$ & $\begin{array}{l}2.5 \mathrm{mo} \\
(1-4)\end{array}$ & $\begin{array}{l}\text { CR: clinical } \\
\text { remission. } \\
\text { PR: improvement } \\
\text { or stabilization of } \\
\text { symptoms. }\end{array}$ & $\begin{array}{l}25 \mathrm{mo} \\
(13-29.5)\end{array}$ & $\begin{array}{l}2(50 \%) . \\
\text { - Additional doses of } \\
\text { rituximab (1) } \\
\text { - No treatment (1) }\end{array}$ \\
\hline $\begin{array}{l}\text { Minimal change } \\
\text { glomerulonephritis } \\
(n=3)\end{array}$ & $\begin{array}{l}43 \mathrm{y} \\
(38-50) \\
67 \% \mathrm{M}\end{array}$ & $\begin{array}{l}24 \mathrm{~h} \text { proteinuria } \\
\text { (>1,5 } \mathrm{g} \text { in } 2 \text { cases; } \\
\text { edemas in the other } \\
\text { one, but not } \\
\text { quantified). }\end{array}$ & $\begin{array}{l}\text { - Corticosteroids and } \\
\text { mycophenolate +/- ACE } \\
\text { inhibitor (2). } \\
\text { - Cyclosporin (1). }\end{array}$ & $\begin{array}{l}375 \mathrm{mg} / \mathrm{m}^{2} \text { weekly ( } \\
2-4 \text { doses); ( } 66.6 \% \\
\text { of cases). }\end{array}$ & $\begin{array}{l}2 \mathrm{mo} \\
(1.25-3)\end{array}$ & $\begin{array}{l}\text { CR: proteinuria } \leq \\
500 \mathrm{mg} / 24 \mathrm{~h} . \\
\text { PR: improvement } \\
\geq 50 \% \text { of } 24 \mathrm{~h} \\
\text { proteinuria. }\end{array}$ & $\begin{array}{l}25 \mathrm{mo} \\
(24.5-28)\end{array}$ & $\begin{array}{l}2(66.6 \%) . \\
\text { - No treatment }\end{array}$ \\
\hline $\begin{array}{l}\text { Desensitization anti- } \\
\text { HLA before } \\
\text { transplantation }(n=2)\end{array}$ & $\begin{array}{l}41.5 \mathrm{y} \\
(41-42) \\
50 \% \mathrm{M} / \\
50 \% \mathrm{~F}\end{array}$ & $\begin{array}{l}\text { Presence of } \\
\text { antibody anti-HLA } \\
\text { before } \\
\text { transplantation. }\end{array}$ & & $\begin{array}{l}1 \mathrm{~g} \text { IV } 2 \text { weeks apart } \\
\text { (50\% of cases) } \\
\text { Intravenous } \\
\text { immunoglobulin and } \\
\text { plasmapheresis (2). }\end{array}$ & & $\begin{array}{l}\text { CR: No reject. } \\
\text { PR: Analytical } \\
\text { response. }\end{array}$ & $\begin{array}{l}23 \mathrm{mo} \\
(18-28)\end{array}$ & $\begin{array}{l}2(100 \%) . \\
\text { - No treatment }(2)\end{array}$ \\
\hline
\end{tabular}




\begin{tabular}{|c|c|c|c|c|c|c|c|c|}
\hline $\begin{array}{l}\text { Thrombotic } \\
\text { thrombocytopenic } \\
\text { purpura }(n=2)\end{array}$ & $\begin{array}{l}47 \mathrm{y} \\
(39-55) \\
50 \% \mathrm{M} / \\
50 \% \mathrm{~F}\end{array}$ & $\begin{array}{l}\text { Platelet count } \\
\leq 20 \times 10^{9} / \mathrm{L}\end{array}$ & $\begin{array}{l}\text { Plasmapheresis } \pm \\
\text { corticosteroids. }\end{array}$ & $\begin{array}{l}375 \mathrm{mg} / \mathrm{m}^{2} \text { weekly } \\
\text { (2-4 doses). }\end{array}$ & $\begin{array}{l}0.75 \mathrm{mo} \\
(0.5-1)\end{array}$ & $\begin{array}{l}\text { CR: platelet count } \\
>150 \times 10^{9} / \mathrm{L} . \\
\text { PR: Platelet count } \\
>50 \times 10^{9} / \mathrm{L} .\end{array}$ & $\begin{array}{l}16 \mathrm{mo} \\
(1-31)\end{array}$ & $\begin{array}{l}2(100 \%) . \\
\text { Plasmapheresis and } \\
\text { additional doses of } \\
\text { rituximab in } 1 \text { case. }\end{array}$ \\
\hline
\end{tabular}

${ }^{a}$ Data of indications with only one case are not shown.

${ }^{\mathrm{b}}$ One case of lupus nephritis also had hemolytic anaemia (haemoglobin $6 \mathrm{~g} / \mathrm{dL}$ ) that was resolved after treatment.

${ }^{\mathrm{c}}$ Stage according to the modified Rai classification.

IQR: Interquartile range; CR: Complete response; PR: Partial response; R-EPOC: rituximab, etoposide, prednisone, vincristine, and doxorubicin. 